\title{
TURISMO URBANO E CRIMINALIDADE UMA CORRELAÇÃO CURITIBANA NO SÉCULO XXI ${ }^{1}$.
}

\author{
Nelson Argentino Soares Junior ${ }^{2}$
}

Este trabalho propõe um estudo pautado nos fundamentos da Geografia na tentativa de migrar de uma preocupação cotidiana para uma temática acadêmica, ou seja, avaliar se existe correlação entre turismo urbano e a criminalidade, pautando sempre pela construção de uma argumentação coerente para a produção de um conhecimento. Nesta perspectiva, procurou-se fundamentar este estudo em referências teóricas de autores que trataram os temas "turismo urbano" e "crime, criminalidade e violência", especialmente aqueles que permitiam estabelecer uma correlação entre eles, tentando oferecer uma leitura alternativa às abordagens dos mesmos. Assim sendo, embora o turismo urbano seja uma atividade bastante discutida e estudada no campo da Geografia, sua correlação com a criminalidade é um objeto de pesquisa que pode e precisa ser analisado de maneira coerente com o conhecimento geográfico, contudo não se pretende com este trabalho dizer o que é "certo" ou "errado", pois isto é um juízo de valores sobre uma realidade que pode ser percebida diferentemente. Dentro desta perspectiva, a escolha por um objeto de estudo recaiu sobre a cidade de Curitiba, no período entre 2000 e 2005, pois muito se fala da transformação da provinciana "Capital Ecológica" na Metrópole que não estava preparada para o crescimento descontrolado e inesperado, por conta de uma intensa propaganda de suas "qualidades" urbanísticas e também pela instalação de um pólo automobilístico em sua Região Metropolitana. Em suma, o objetivo deste trabalho é procurar analisar a correlação entre turismo urbano e criminalidade na cidade de Curitiba, através de uma busca na bibliografia já produzida sobre estes dois temas urbanos, bem como através da pesquisa de dados nos campos do Turismo Local e da Segurança Pública. Desse modo, se procura uma nova leitura da cidade. Neste contexto, a abordagem deste tema e os autores escolhidos para fundamentar a pesquisa dão a este estudo a condição de científico e específico. Esta base teórica tem como finalidade debater o tema também a partir dos recursos de outras áreas do conhecimento, que não apenas os da Geografia Urbana. O presente trabalho procura argumentar que ocorrem mudanças significativas no cotidiano das cidades pela redefinição do modo de vida urbano, e a percepção desta mudança ruma a compreensão de que a violência urbana tornou-se uma questão essencialmente geográfica. Em outras palavras, o presente estudo da correlação entre turismo urbano e criminalidade em Curitiba procura agir como uma lente sobre o tema, uma exposição sobre o que pensa este pesquisador, tentando fazer deste trabalho uma contribuição para a ciência.

PALAVRAS-CHAVE: turismo urbano; criminalidade; segurança pública.

\footnotetext{
${ }^{1}$ Orientador: Prof. Dr. Marcos Aurélio Tarlombani da Silveira

2 Mestrando em Geografia (UFPR) - e-mail: nelson_mestrado@zipmail.com.br
} 